第 16 回 日本臨床薬理学会 1995 年 11 月 $1 \sim 2$ 日 東京・明治記念館

\title{
リドカインおよびミダゾラムのマウス受動的回避反応 に及ぼす影響
}

\author{
内 橋 慶 隆* 中 井 哲 慈* 唐 沢 富士夫* \\ 佐 藤 哲 雄*
}

局所麻酔下での手術の際、鎮静を目的として ベンゾジアゼピン系の薬物が併用されることが ある。またベンゾジアゼピン系薬物は健忘作用 も有するとされ、手術中の不快な記憶が残らな い利点も期待される 1)。一方局所麻酔薬は中 枢作用も合わせ持ち、GABA、グルタミン酸、 モノアミン、アセチルコリン等の脳内神経伝達 物質に影響を及ぼすと言われている2)。これ らの脳内神経伝達物質は学習・記憶に重要な働 きをしていると考えられており、局所麻酔薬が ベンゾジアゼピン系薬物の健忘作用を修飾する 可能性がある。

本実験は臨床的に汎用されるリドカインとミ ダゾラムを用いて、局所麻酔薬がベンゾジアゼ ピン系薬物の健忘作用に影響を及ぼすかを動物 実験で調べることを目的とした。記憶の指標と しては、受動的回避反応の反応潜時を用いた。

\section{対象および方法}

実験には 7 週齢のddY系雄性マウス（体重24 〜34 g) を使用した。

実験 1 : 明暗 2 室からなるステップ・スルー 型受動的回避実験箱を用い、明室内のマウスが 暗室にはいるまでの時間（反応潜時）を測定し た。リドカイン (10、20、40 mg/kg)、ミダゾラ

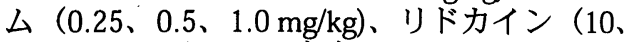

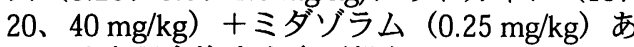
るいは生理食塩水を皮下投与し、10分後マウス を明室に置き、反応潜時を測定した。その後暗 室内のマウスに床グリッドを通して電気刺激

（100V、5秒間）を与えた（獲得試行)。その24 時間後、再び反応潜時を測定した（再生試 行)。なお、リドカイン投与量はマウスに痙變

\footnotetext{
* 防衛医科大学校麻酔科 干 359 所沢市並木 3-2
}

が生じない用量を使用した。またリドカイン

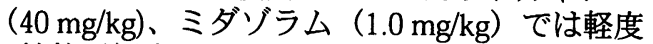
の鎮静が観察されたが、正向反射は消失しな かった。

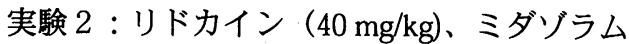

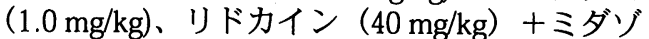
ラム $(0.25 \mathrm{mg} / \mathrm{kg})$ あるいは生理食塩水を皮下投 与し、10分後電気刺激に対する疼痛閵值を調べ た。疼痛閥値はflinch とvocalizationを指標にし た。

実験 3 : リドカイン $(40 \mathrm{mg} / \mathrm{kg})$ を皮下投与 後、3、5、10、20分に心蔵より採血し、ガスク ロマトグラフィにて血中濃度を測定した。

統計処理はKruskal-Wallisノンパラメトリック 分散分析と、Mann-Whitney U検定を使用した。

\section{結果}

実験 1 : 生理食塩水を投与したマウスは、獲 得試行では速やかに明室より暗室内に入った が、再生試行では入りにくくなり、反応潜時が 著明に延長した。この再生試行潜時の延長は、 リドカインあるいはミダゾラムの投与で用量依 存的に抑制され、リドカイン $(20 、 40 \mathrm{mg} / \mathrm{kg})$ 、 ミダゾラム $(1 \mathrm{mg} / \mathrm{kg})$ で有意であった。また効 果を示さない用量のミダゾラム $(0.25 \mathrm{mg} / \mathrm{kg})$ を リドカインと併用投与すると、リドカイン単独 投与の効果を有意に増強した（Table 1)。

実験 2 : リドカインあるいはミダゾラム単独 投与、リドカインとミダゾラム併用投与はflinch およびvocalizationに有意な影響を与えなかった。

実験 3 : リドカインの血中濃度は5〜10分後に ピークを示し、平均濃度は6.1〜 7.4 $\mu \mathrm{g} / \mathrm{ml}$ であっ た。

考察

生理食塩水投与群における再生試行潜時の延 長は、マウスが獲得試行時の暗室内での不快刺 激（電気刺激）を学習、記憶したことにより暗 
Table 1. Effects of lidocaine and/or midazolam on the step-through latency in passive avoidance learning in mice.

\begin{tabular}{lllcc}
\hline Treatment & $\begin{array}{l}\text { Dose } \\
(\mathrm{mg} / \mathrm{kg})\end{array}$ & $\mathrm{N}$ & \multicolumn{2}{c}{ Step-through latency $(\mathrm{s})$} \\
\cline { 4 - 5 } & & & Training trial & Retention trial \\
\hline Saline & - & 20 & $10.1 \pm 0.8$ & $508.2 \pm 34.8$ \\
Lidocaine & 10 & 20 & $8.7 \pm 1.1$ & $453.8 \pm 43.5$ \\
& 20 & 20 & $7.3 \pm 0.6$ & $396.6 \pm 39.0^{\$}$ \\
& 40 & 20 & $8.3 \pm 1.2$ & $184.2 \pm 36.5^{\$}$ \\
Midazolam & 0.25 & 20 & $9.3 \pm 1.1$ & $487.8 \pm 37.5$ \\
& 0.5 & 20 & $9.9 \pm 0.9$ & $371.2 \pm 49.8^{\$}$ \\
& 1 & 20 & $12.3 \pm 1.2$ & $189.1 \pm 39.9^{\$}$ \\
Lidocaine & 10 & 20 & $9.9 \pm 1.14$ & $298.9 \pm 45.0^{\& \#}$ \\
+ & 20 & 19 & $7.0 \pm 0.8$ & $191.2 \pm 40.8^{\&}$ \&\# \\
& 40 & 20 & $9.9 \pm 1.7$ & $80.3 \pm 35.3^{8}$ \\
Midazolam & 0.25 & & & \\
\hline
\end{tabular}

Each value represents mean \pm S.E.M. ${ }^{\$}$ Statistically significant difference from the saline-treated group $(\mathrm{P}<0.05)$; \& Statistically significant difference from the midazolam-treated group $(0.25 \mathrm{mg} / \mathrm{kg})$ $(P<0.05)$; \# Statistically significant difference from the corresponding dose in the lidocaine-treated group $(\mathrm{P}<0.05)$.

室内に入ることを踏躇するようになったためと 考えられる。リドカインおよびミダゾラムは用 量依存的に潜時延長を抑制した。この抑制は疼 痛閥值の上昇といった単なる知覚の変化に起因 するものではない。ミダゾラムなどのベンゾジ アゼピン系の薬物は、情報が脳内の記憶回路に 入力されるのを阻害することにより健忘を引き 起こすとされている 3$)$ 。従ってリドカインや ミダゾラムによる受動的回避反応の抑制は、不 快刺激の脳内への入力が障害されたために生じ た可能性がある。

リドカイン $40 \mathrm{mg} / \mathrm{kg}$ 投与後は痙卛等の明らか な中毒症状は観察されなかったが、血中濃度か らみると中毒量に近いものと考えられる。仮に リドカインがヒトにも健忘を引き起こすとして も、局麻中毒症状 (意識混濁等) による非特異 的な反応の可能性がある。しかし無効量のミダ ゾラムがリドカインの作用を増強したことよ り、臨床的には通常量のリドカイン局所麻酔下 において少量のミダゾラムを併用投与すること で、ミダゾラムの副作用（呼吸抑制や過度な鎮
静等) 1 ）に注意を払うことなく安全に手術中の 記憶を減少できることが示唆される。

記憶の指標として単に受動的回避反応の潜時 の長短を論じるのは不適切との意見もあり 3 )、 他の学習実験等もふまえたさらに慎重な検討が 必要である。

\section{参考文献}

1) Reinhart. K., Dallinger-Stiller, G., Dennhardt, R. et al.: Comparison of midazolam, diazepam and placebo i.m. as premedication for regional anaesthesia. Br. J. Anaesth. 57 : 294-299 (1985).

2) Garfield, J. M. and Gugino, L.: Central effects of local anesthetic agents. Strichartz, G. R. (Ed.) Local Anesthetics, Springer-Verlag, Berlin Heidelberg New York, pp. 253-284 (1987).

3）栗原 久, 田所作太郎：学習・記憶の動物実 験. 田所作太郎（編）: 行動薬理学の実践一薬 物による行動変化一, 星和書店, 東京, pp. 115144 (1991). 